\title{
ARTIKELEN
}

\section{Preventie is niet vrijblijvend}

\section{Over het preventie-oeuvre van Jos Dute}

Prof. mr. B.C.A. Toebes ${ }^{*}$

\section{Introductie}

Naast zijn werk over de regulering van de zorg heeft Jos Dute veel geschreven over preventie. Deze publicaties bestrijken een breed scala aan onderwerpen, variërend van de internationale en nationale regulering ter bestrijding van infectieziekten, de bescherming van de rechten van geïnfecteerden en gedetineerden, de vaccinatieplicht, neonatale screening en het reguleren van ongezond gedrag. Met recht kan gezegd worden dat Jos Dute de afgelopen decennia een van de belangrijkste, zo niet de belangrijkste stempel heeft gedrukt op het preventierecht in Nederland.

In deze bijdrage bespreek ik Dutes indrukwekkende preventie-oeuvre. Ik begin met Jos' inaugurale rede, waarin hij blijk geeft van zijn bredere gedachtengoed op het vlak van preventie. Vervolgens richt $\mathrm{ik}$ mij uitgebreid op de bestrijding van infectieziekten in het licht van de recente uitbraak van COVID-19, en in beperktere mate op de regulering van alcohol. Ik leg hierbij uit hoe het werk van Jos van pas komt bij deze vraagstukken. Ik doe hiermee geen recht aan alles wat Jos geschreven heeft, maar ik hoop in deze korte bijdrage te laten zien wat zijn werk heeft bijgedragen aan het preventierecht, en hoe het ons kan blijven inspireren.

\section{Oratie 'De vrijblijvendheid voorbij - over het recht op preventie'}

In 2013 sprak Jos Dute zijn inaugurale rede uit aan de Radboud Universiteit Nijmegen. ${ }^{1}$ Deze pakkend geschreven rede vormt een dwingend betoog voor meer aandacht voor preventie door overheid en gezondheidsjuristen. Ik citeer uit zijn conclusies:

'Preventie is een ondergewaardeerd rechtsgoed. Vormt de gezondheidszorg een stevig in het recht verankerd gebouw, preventie is een conglomeraat van gebouwen en gebouwtjes, soms met een zwakke juridische fundering. Daarbij is de curatieve gezondheidszorg eerder de concurrent dan het complement van preventie.'

* Brigit Toebes is hoogleraar Gezondheidsrecht in Internationaal Perspectief aan de Rijksuniversiteit Groningen.

1 J.C.J. Dute, De vrijblijvendheid voorbij. Over het recht op preventie, Nijmegen: Radboud Universiteit Nijmegen, 2013. 
Dutes rede is voorts heel duidelijk geïnspireerd door mensenrechten. Hij pleit voor een op mensenrechten gebaseerde aandacht voor preventie die niet vrijblijvend is:

'Preventie dient naar mijn overtuiging meer in de sleutel van de mensenrechten te worden geplaatst. Dan wordt zichtbaar dat over preventie nu nog te veel wordt gedacht in termen van beleid en te weinig in termen van recht, te veel in termen van vrijheidsbeperking en te weinig in termen van juridisch geborgde beschikbaarheid en bereikbaarheid, betaalbaarheid en kwaliteit. Preventie is een kwetsbaar goed en dient naar mijn overtuiging gezondheidsrechtelijk beter te worden verankerd.'2

Hiermee zet Dute het 'recht op preventie' voor het eerst op de kaart in Nederland. Dute betoogt dat het recht op preventie voortvloeit uit het recht op gezondheid, zoals geformuleerd in internationale en regionale mensenrechtenverdragen, en - als opdracht aan de overheid - in onze Grondwet. Er is in deze bepalingen sprake van een aantal zeer expliciete verwijzingen naar preventie, hetgeen laat zien dat het grond- en mensenrechtenkader een duidelijke grondslag biedt voor een recht op preventie zoals Jos dat vormgeeft in zijn oratie. $^{3}$ Door preventie te benaderen vanuit mensenrechten legt Dute heel duidelijk de nadruk op de kwetsbaarheid van het individu en het belang van solidariteit. Dus alhoewel hij de kans om kosten te besparen wel degelijk noemt, ligt zijn nadruk ligt bij de belangen van het individu. Hier toont Dute zijn mensenrechten-hart.

Ook maakt Dute in zijn oratie een aantal interessante opmerkingen over de huidige regulering rond publieke gezondheid onder de Wet publieke gezondheid (Wpg). Deze wetgeving richt zich voornamelijk op de bestrijding van infectieziekten. Hij constateert dat de verantwoordelijkheid voor de publieke gezondheid en daarmee de infectieziektenbestrijding voornamelijk bij gemeenten lag, en dat de Wpg enkele malen is aangepast om te voorzien in meer centrale aansturing ten behoeve van de opsporing en bestrijding van infectieziekten. Het lijkt zinvol om na afloop van de huidige COVID-19-uitbraak kritisch te evalueren of de huidige taakverdeling goed functioneert in geval van een ernstige uitbraak van een infectieziekte.

Dute spreekt daarnaast zijn teleurstelling uit over de beperkte reikwijdte van de Wpg met de eenzijdige nadruk op infectieziektenbestrijding. Hij noemt de wet een papieren tijger en wijst in dit verband naar een voorstel om naar analogie van de Franse Code de la santé publique een wetboek voor de volksgezondheid te ontwerpen. ${ }^{4}$ In deze wet zouden naast de Wpg onder meer de Tabakswet, de Drank- en Horecawet, de Wet op het bevolkingsonderzoek en de Warenwet als hoofdstukken moeten worden opgenomen. ${ }^{5}$ Dute is niet per se voor een dergelijke constructie, maar hij suggereert wel dat elementen van preventie beter juridisch verankerd zouden kunnen worden. Ook benadrukt hij dat op het niveau

2 Dute 2013.

3 In ons Preadvies Ongezond gedrag: de rol van het recht (2019) werken wij dit nader uit (zie met name hoofdstuk I, 'Introductie').

4 Dute 2013, p. 22; onder verwijzing naar W. van den Ouwelant, Heilzame wetten - Historie, karakter, plaats en vorm van de publieke gezondheidszorg, Preadvies Vereniging voor Gezondheidsrecht 2005, Den Haag: Sdu Uitgevers, 2005, p. 92 (voorstel W. van den Ouwelant).

5 Dute 2013, p. 16-17. 
van de Europese Unie veel werk gedaan zou moeten worden. ${ }^{6}$ Dit laatste komt ook zeker naar boven in de huidige COVID-19-crisis.

\section{Regulering van infectieziekten en COVID-19}

Op het moment van het schrijven van deze bijdrage beheerst de uitbraak van het coronavirus ons gehele leven. Het is voor het eerst sinds de Tweede Wereldoorlog dat wij een crisis meemaken van deze omvang, één die noopt tot noodmaatregelen en vergaande beperkingen van grond- en mensenrechten. De uitbraak houdt politici, zorgverleners, docenten en alle anderen met vitale beroepen vaak dag en nacht bezig; scholieren, studenten en de meeste werknemers zitten onverhoopt thuis en proberen er het beste van te maken.

Toen Jos Dute in 1994 zijn proefschrift over de wetgeving ter bestrijding van infectieziekten verdedigde, ${ }^{7}$ had hij niet kunnen bevroeden dat zich tijdens zijn leven een crisis van deze omvang zou voordoen. Het door hem ontwikkelde gedachtengoed komt in deze crisis goed van pas. Wetgeving is hier en daar veranderd, maar zijn werk over grond- en mensenrechten en internationale regulering is van blijvend belang. ${ }^{8}$ Terugblikkend op Dutes werk, wat zijn de lessen voor de huidige crisis?

Zoals Dute ook beschrijft in zijn proefschrift, ${ }^{9}$ werken landen reeds anderhalve eeuw samen als het gaat om de bestrijding van infectieziekten. Sinds de 19e eeuw bestaan er internationale 'sanitaire' regelingen ter bestrijding van infectieziekten. De uitbraak van het coronavirus (COVID-19) wordt gereguleerd door de herziene Internationale Gezondheidsregeling (IHR) van de Wereldgezondheidsorganisatie (WHO), die sinds 2007 bindend is voor alle landen ter wereld. ${ }^{10}$

Zoals Dute constateert, vormt de nieuwe Regeling een verbetering vanwege haar open formulering: alle bedreigingen van de volksgezondheid vallen eronder, dus niet meer alleen een beperkt omschreven lijst van ziekten. ${ }^{11}$ Het instrument schiet echter tekort als het gaat om het opleggen van bindende maatregelen aan staten. De WHO kan lidstaten geen sancties opleggen. Veel wordt daarmee overgelaten aan de bereidheid van landen om de aanbe-

$6 \quad$ Dute 2013, p. 14 en 22.

7 J.C.J. Dute, De wetgeving ter bestrijding van infectieziekten, Nijmegen: Ars Aequi Libri, 1994.

8 Een greep uit de lange publicatielijst: J.C.J. Dute, De wetgeving ter bestrijding van infectieziekten, Nijmegen: Ars Aequi Libri 1994; J.C.J. Dute, 'Affected by the Tooth of Time: Legislation on Infectious Disease Control in Five European Countries', Medicine and Law 1993 (12) 1/2, p. 101-109; J.C.J. Dute, 'Legislation on infectious disease control', Netherlands Journal of Medicine 1998 (52) 6, p. 277-281; en J.C.J. Dute, 'Juridische aspecten van hepatitis B in zorginstellingen', TvGR 2001, p. 286-297.

9 Dute 1994, p. 64.

10 WHO, Internationale Gezondheidsregeling, aangenomen te Genève op 23 mei 2005, in werking sinds 15 juni 2007.

11 Zie onder meer J.C.J. Dute, 'De bestrijding van infectieziekten in een veellagige rechtsorde', in: A.C. Hendriks en H-M.Th.D. ten Napel (red.), Volksgezondheid in een veellagige rechtsorde, Eenheid en verscheidenheid van norm en praktijk, Alphen aan den Rijn: Kluwer 2007, p. 123-136, op p. 132. Sinds de nieuwe Regeling is een zestal keer sprake geweest van een uitbraak van een infectieziekte die kwalificeerde als noodsituatie: influenza in Mexico (2009), ebola in West-Afrika (2014); polio in Pakistan, Afghanistan en Nigeria (2014); zika in ZuidAmerika (2016); ebola in Congo (2018) en nu dus COVID-19 in China. 
velingen van de WHO op te volgen. Niettemin biedt de vernieuwde IHR volgens Dute een potentieel kader voor een 'snelle, gecoördineerde en beheerste respons op een (mogelijke) uitbraak van een infectieziekte met grensoverschrijdende implicaties'. ${ }^{12} \mathrm{Ik}$ citeer de profetische woorden van Dute: 'Of de IHR ook werkelijk daartoe zullen leiden, zal de tijd leren. Zo niet, dan toch zeker hier geldt: the proof of the pudding is in the eating ${ }^{13}$ Kunnen we bij de COVID-19-uitbraak inderdaad spreken van een 'snelle, gecoördineerde en beheerste respons'? Hoe functioneert de IHR en wat is daarnaast de rol van mensenrechten? Laten we met China beginnen, en dan het blikveld verschuiven naar Europa, waar op het moment van schrijven het epicentrum van de uitbraak ligt.

Terwijl het virus ongeveer begin december werd ontdekt, rapporteerde China op 31 december 2019 aan de WHO dat er sprake was van een uitbraak. Hier gingen dus enkele weken overheen. Op basis van de Internationale Gezondheidsregeling dienen landen binnen 24 uur te rapporteren. ${ }^{14}$ Dit lijkt een detail, maar kan voor het verloop van de ziekte van wezenlijk belang zijn geweest. ${ }^{15}$ Het is dus belangrijk te constateren dat China de WHO niet onmiddellijk op de hoogte heeft gesteld. Er zijn ook geluiden dat een arts door de autoriteiten de mond gesnoerd is. ${ }^{16}$ Hier moeten we dus constateren dat China mogelijk de IGR geschonden heeft, maar dat het de WHO aan sanctiemiddelen ontbreekt om China hierop aan te spreken. ${ }^{17}$

Toch kunnen we wel spreken van een relatief snelle en effectieve respons zoals door Dute gepredikt. Op 30 januari, dus een maand later, verklaarde de WHO dat er sprake was van een internationale noodsituatie die een bedreiging vormt voor de volksgezondheid. ${ }^{18}$ Vergeleken met de stroperige reactie op de uitbraak van ebola in West-Afrika is deze reactie een verbetering: binnen een maand was de uitbraak wereldnieuws en werd actie genomen. Vervolgens deed de WHO een set aanbevelingen, waarna een intensieve samenwerking met China tot stand leek te komen. ${ }^{19}$ China reageerde op de uitbraak van het virus met het opleggen van zeer uitgebreide quarantaines, onder meer door de elf miljoen inwoners van de stad Wuhan te verbieden de stad te verlaten. Vanuit volksgezondheidsperspectief is te waarderen dat China zo alert heeft gereageerd.

Laten wij de blik verschuiven naar Europa. Hier zien wij verschillende scenario's, variërend van een complete lockdown vergelijkbaar met China tot een set maatregelen die de bewegingsvrijheid van het individu drastisch of minder drastisch beperken. Een aantal landen

12 Dute 2007, p. 132.

13 Idem.

14 Art. 6-1 IGR.

15 David Cyranoski, 'What China's coronavirus response can teach the rest of the world', Nature - News Explainer, 17 maart 2020.

16 Human Rights Watch, 'Wuhan Whistleblower Doctor Dies: Daily Brief', 7 februari 2020, hrw.org.

17 Zie Pedro Villareal, 'The (not so) Hard Side of the IHR: Breaches of Legal Obligations', Global Health Law Groningen Blog, 26 februari 2020, www.rug.nl/rechten/onderzoek/expertisecentra/ghlg/blog.

18 Art. 12 IGR. Zie bijvoorbeeld J.C.J. Dute, 'Revision of the International Health Regulations', European Journal of Health Law 11 (2005) 3, p. 269-271.

19 Zie WHO, 'Report of the WHO-China joint mission on Coronavirus Disease 2019 (COVID-2019)', 16-24 februari 2020, www.who.int/docs/default-source/coronaviruse/who-china-joint-mission-on-covid-19-finalreport.pdf. 
heeft de noodtoestand uitgeroepen en kan daarmee rechten als privacy en bewegingsvrijheid volledig opzijzetten. Nederland kiest vergeleken bij deze landen op dit moment een gematigder benadering: de mensen mogen nog de straat op en het economische en sociale leven ligt niet volledig plat.

De vraag die hier speelt is hoe ver je kunt gaan om de volksgezondheid te beschermen ten koste van die individuele rechten als persoonlijke levenssfeer, fysieke integriteit en bewegingsvrijheid. ${ }^{20}$ Voor Dute vormen de grond- en mensenrechten het cruciale startpunt om te beoordelen of de maatregelen ter bestrijding van infectieziekten gerechtvaardigd zijn. In zijn werk bespreekt hij met name inperkingen van de vrijheid van een individu met een infectieziekte. Dwang is volgens Dute dan alleen gerechtvaardigd indien het noodzakelijk is om anderen te beschermen tegen serieuze aantastingen van hun gezondheid. Dute beroept zich hierbij op het schadebeginsel ('no harm principle'), zoals verwoord door John Stuart Mill en ook in het strafrecht erkend. ${ }^{21}$ Ik citeer Dute:

'overheidsdwang ten behoeve van infectieziekten vindt zijn rechtvaardiging uiteindelijk in de afwending of beperking van gevaar voor leven en / of (ernstige) schade aan gezondheid van andere personen. ${ }^{22}$

Volgens Dute is het schadebeginsel als rechtsgrond onomstreden en heeft het internationaal brede erkenning gekregen. ${ }^{23}$

Het gevaarscriterium werpt echter een beperkt licht op de recente COVID-19-uitbraak en op de reikwijdte van collectieve volksgezondheidsmaatregelen. Immers, hebben we het alleen over gevaar voor derden, of veelal juist over gevaar voor mensen zelf? De overheid dient ook maatregelen te nemen om niet-geïnfecteerden tegen zichzelf te beschermen. De gezonde 80-jarige en de COPD-patiënt brengen toch voornamelijk zichzelf in gevaar indien zij zich onder de mensen begeven? Een te grote nadruk op het gevaarscriterium vertroebelt mijns inziens de discussie.

Niettemin is er in Dutes werk ook veel ruimte voor nuance rond dit begrip. Dutes proefschrift bevat een gedetailleerde uiteenzetting van de vraag waarom de overheid voor de bestrijding van infectieziekten de individuele vrijheid zou mogen beperken. ${ }^{24}$ Omdat deze uiteenzetting mooi aansluit bij de huidige discussie over 'proportionaliteit' van de genomen maatregelen in de huidige COVID-19-discussie, wil ik deze hier nog eens opdiepen. ${ }^{25}$ Dute presenteert in zijn proefschrift een normatief kader ter bestrijding van infectieziekten dat uit drie componenten bestaat: wettelijke grondslag, noodzaak en waarborg. ${ }^{26}$

20 Zie ook Brigit Toebes, 'Uitbraak COVID-19 is een zaak van internationaal recht en mensenrechten', Global Health Law Groningen Blog, 22 maart 2020, www.rug.nl/rechten/onderzoek/expertisecentra/ghlg/blog.

21 Dute 1998, p. 278 (zie noot 8 van deze bijdrage).

22 Dute 2005, p. 111 en Dute 1994, p. 144-145.

23 Dute 2005, p. 111.

24 Dute 1994, p. 144.

25 Brigit Toebes en Alex Friedrich, 'Grijp nog fermer in om corona in te dammen', NRC-Handelsblad, 12 maart 2020.

26 Dute 1994, p. 150-155. 
De voorwaarde van een 'wettelijke grondslag' vereist dat overheidsbeperkingen die inbreuk maken op de vrijheidssfeer van de burger steunen op een wet. De Wet publieke gezondheid (Wpg) is in dit kader van groot belang. COVID-19 is op basis van deze wet ingedeeld categorie A: de hoogste categorie, op basis waarvan overheid een reeks dwingende maatregelen kan nemen zoals opname tot isolatie in een ziekenhuis en thuisisolatie. ${ }^{27}$ Daarnaast kent de Wpg in samenhang met de Wet veiligheidsregio's de voorzitters van de veiligheidsregio's een aantal verantwoordelijkheden toe. ${ }^{28} \mathrm{Zij}$ maken - in plaats van de burgemeesters - gebruik van de noodverordeningsbevoegdheid, bijvoorbeeld om samenscholing te verbieden. Zij doen dit deels op laste van de Minister van Volksgezondheid. ${ }^{29}$ Deze wettelijke bevoegdheidsafbakening tussen veiligheidsregio's en gemeenten zal in de evaluatie van het overheidsingrijpen in het kader van COVID-19 ongetwijfeld ter discussie staan. Nu de burgemeesters door deze methodiek opzij zijn gezet, is er onder meer zorg over de democratische controle van deze maatregelen door de gemeenteraden. ${ }^{30}$

Wat het vereiste van 'waarborg' betreft: dit vereist dat degene die de maatregel moet ondergaan voldoende wordt beschermd. De norm in kwestie moet toetsbaar zijn, en de rechtspositie van deze persoon dient beschermd te zijn. ${ }^{31}$ Ook deze bescherming zal ongetwijfeld ter discussie staan na afloop van de crisis. Zo roept Hendriks vragen op over de positie van ouderen die gedwongen in een instelling zitten. Zij kunnen op dit moment niet fysiek overleggen met een advocaat, omdat die niet toegelaten wordt tot verpleeghuizen. ${ }^{32}$

Het middelste criterium - 'noodzaak' - krijgt in Dutes proefschrift de meeste aandacht: de dwang die toegepast wordt dient noodzakelijk te zijn. Hier zien wij een parallel met de huidige discussie omtrent 'proportionaliteit' in de COVID-19-discussie: heiligt het doel de middelen? Om te bepalen of een maatregel noodzakelijk is, biedt Dute een 17-tal criteria die de moeite waard zijn om nog eens af te stoffen. De overheid verplicht ons tijdens deze uitbraak thuis te blijven en mag dat ook handhaven. Wat betekent dit volgens de criteria van Dute?

27 Zie ook A.J. Wierenga en J.G. Brouwer, 'Coronacrisis en het recht (deel 1)', Centrum voor Openbare Orde en Veiligheid, 16 maart 2020, zie www.openbareorde.nl/tijdschrift/coronacrisis-en-het-recht-deel-1/.

28 Art. 6(2) en 7(1) Wpg en art. 39 Wet veiligheidsregio’s (Wvr). Voor een discussie zie ook Aart Hendriks, 'Nood breekt wet in tijden van corona', NJB 2020/880, 10 april 2020, afl 14, p. 949-955.

29 A.J. Wierenga en J.G. Brouwer, 'Coronacrisis en het recht (deel 6)', Centrum voor Openbare Orde en Veiligheid, 29 maart 2020, zie www.openbareorde.nl/tijdschrift/coronacrisis-en-het-recht-deel-6/.

30 Directoraat-Generaal Politie en Veiligheidsregio's, Antwoorden Kamervragen over de lokale noodverordeningen in verband met de bestrijding van het coronavirus, 1 april 2020.

31 Dute 1994, p. 151-153.

32 Hendriks 2020, zie noot 28 van deze bijdrage, p. 953. 
Tabel 1 Dutes 'Nadere uitwerking van het noodzakelijkheidsvereiste.33

\section{Criterium voor beperken individuele vrijheid \\ I. De ernst van de ziekte \\ 2. Het achterhalen van restverschijnselen (e.g. invaliditeit) \\ 3. De snelheid waarmee de ziekte zich kan verspreiden \\ 4. Het aantal personen dat door de ziekte wordt bedreigd \\ 5. De mate waarin de ziekte zich heeft verspreid \\ 6. De wijze waarop de ziekte wordt overgedragen \\ 7. De mate waarin men zich tegen ziekte-overdracht kan beschermen}

8. De mogelijkheid om na besmetting schadepreventief op te treden

9. De periode van besmettelijkheid

10. De effectiviteit van de maatregel

II. De effectiviteit van minder ingrijpende maatregelen

12. De effectiviteit van niet op individuele personen gerichte maatregelen

13. De gedragsafhankelijkheid van de ziekte

14. De omgevingsbepaaldheid van de verspreiding van de ziekte

15. De mogelijkheid om de ziekte medisch te behandelen

16. De mate waarin de ziekte maatschappelijk 'beladen' is

17. De totaliteit van grondrechtenbeperking
COVID-I 9 i.v.m.

verplicht thuisblijven

Varieert sterk

Varieert sterk

Snelle verspreiding

Wereldwijde pandemie

Nog geen herd immunity

Besmettelijk

Bescherming niet zodanig dat sociale distantie niet nodig is

Geen vaccin of ander middel

Dagen tot weken

Thuisblijven/sociale distantie lijkt effectief

Mensen houden vrijwillig onvoldoende afstand

Collectieve maatregelen als voorlichting onvoldoende

Sterk gedragsafhankelijk

Verschilt per groep

Zeer beperkt

Niet zeer beladen

Omvangrijke inbreuk

Er is in de COVID-19-discussie veel onduidelijkheid over de betekenis van het begrip 'proportionaliteit'. Een korte evaluatie van de COVID-19-respons aan de hand van de criteria van Dute laat zien dat de Dutes 'drempelwaarden' een aantal prangende vragen opwerpen. Het lijkt belangrijk om vraag 17 (de totaliteit van de grondrechtenbeperking) te beoordelen in het licht van alle andere vragen.

\section{De roep om striktere alcoholregulering}

Wereldwijd en ook in Nederland is sinds een aantal decennia sprake van een sterke stijging van chronische niet-overdraagbare ziekten zoals kanker, diabetes, hart- en vaatziekten. Deze ziekten worden ook wel leefstijlziekten genoemd, omdat zij voor een belangrijk deel (ongeveer de helft) worden veroorzaakt door ongezond gedrag. De Wereldgezondheidsorganisatie (WHO) noemt roken, ongezond dieet, overmatig alcoholgebruik en gebrek aan 
beweging als de vier belangrijkste gedragsrisico's die aan de wortel liggen van deze ziekten. ${ }^{34}$

Het recht is een belangrijk middel om ongezond gedrag terug te dringen. Tabak, ongezond voedsel en alcoholgebruik worden in Nederland tot op zekere hoogte gereguleerd door wetgeving en beleid. Drie maatregelen zijn voor deze drie gedragsrisico's van het grootste belang en gelden als best buys: het verhogen van de prijs, het verbieden van de marketing en het beperken van het aanbod (dit laatste onder meer door het terugdringen van het aantal verkooppunten). ${ }^{35}$ Nederland loopt op niet voorop als het gaat om het reguleren van gedrag, maar heeft recentelijk wel een aantal stappen genomen om bijvoorbeeld tabak strikter te reguleren. Dit is mede ingegeven door het feit dat er sinds 2003 een verdrag is dat tabak regelt: het WHO-Kaderverdrag inzake de Tabaksontmoediging. Het is een open geformuleerd verdrag, maar dankzij dit verdrag zit de tabaksindustrie niet meer aan de tafel als er nieuw tabaksbeleid gemaakt wordt en is het aantal rookvrije ruimtes in Nederland uitgebreid.

Alcoholregulering blijft in Nederland - net als de regulering van ongezond voedsel vooralsnog een ondergeschoven kind. De afwezigheid van een internationaal verdrag wreekt zich hier, evenals de afwezigheid van dwingende EU-regulering. Preadviseurs De Coninck en Dute laten zich hier kritisch over uit in hun bijdrage aan het Preadvies Ongezond gedrag: de rol van het recht, uit 2019. ${ }^{36}$ Juist over de regulering van alcohol is tot dusverre relatief weinig geschreven, wat hun bijdrage aan dit Preadvies des te waardevoller maakt.

Auteurs merken op dat de wetenschappelijke kennis over de schadelijkheid van alcohol de afgelopen jaren aanzienlijk is verbreed. Zij constateren dat de urgentie om alcoholgebruik meer vanuit volksgezondheidsperspectief te reguleren daarmee is toegenomen. In dit licht doen zij een aantal belangrijke aanbevelingen die niet vaak genoeg herhaald kunnen worden. ${ }^{37} \mathrm{Zij}$ pleiten voor meer nadruk op het volksgezondheidsperspectief in de regulering van alcohol, dan onder het huidige regime van de Drank- en Horecawet, die ook sterk de nadruk legt op het handhaven van de openbare orde. Zij tonen zich kritisch over de rol van gemeenten bij het maken van beleid en de handhaving van alcoholgebruik en zij betogen dat deze meer geflankeerd dienen te worden door een krachtig beleid van de centrale overheid, ook om tegenwicht te bieden aan de machtige arm van de alcoholindustrie. Voorts geldt voor wat betreft bovengenoemde drie best buys (prijs, omhoog, terugdringen van marketing en aanbod), ${ }^{38}$ dat zij stuiten op weerstand van de alcoholindustrie en de sterke alcohollobby. De Coninck en Dute tonen zich met name kritisch over de regulering van alcoholreclame en -sponsoring. ${ }^{39}$ Afgezien van een reclameverbod tussen zes uur's ochtends en negen uur's avonds is er namelijk sprake van zelfregulering van de alcoholbranche.

Zie ook B.C.A. Toebes, 'Introductie' bij Preadvies 2019, Ongezond gedrag: de rol van het recht, Den Haag: Sdu 2019, p. 24.

P.J.M. de Coninck en J.C.J. Dute, 'Deel 3: Alcohol', in Preadvies 2019, zie noot 34 van deze bijdrage, p. 177.

Idem.

Idem, p. 211-212.

Idem, p. 207.

Idem, p. 203-204. 
Ik kan niet anders dan het hartgrondig eens zijn met de conclusies die Dute hier samen zijn met coauteur trekt. De regulering van alcohol zou veel meer aandacht moeten krijgen in rechtswetenschappelijk onderzoek en in beleid. Er zou een veel kritischer geluid moeten klinken over de wijze waarop de alcoholindustrie haar macht doet gelden. De bescherming van adolescenten tegen ongebreidelde reclame op onder meer sociale media is hier wat mij betreft een aandachtspunt, evenals ook de prijs, de hoeveelheid en locatie van verkooppunten en de presentatie en etikettering van sommige alcoholproducten.

\section{Slotbeschouwingen}

Jos' werk typeert zich door scherpte in visie en bewoordingen. Zeker als het gaat om preventie komt deze kritische houding goed van pas: op dit terrein viel de afgelopen decennia veel te winnen en hebben overheid en andere verantwoordelijken flinke steken laten vallen. Jos' kritische stem heeft onmiskenbaar bijgedragen aan meer aandacht voor preventie in onderzoek en beleid.

Jos is niet bang om hier en daar een ferme tik uit te delen. Zachte heelmeesters maken stinkende wonden. Zo ook de gezondheidsjurist die niet kritisch is over hetgeen er gezegd en geschreven wordt. En achter die kritische geest gaat een zachtaardig mens schuil, één met het hart op de juiste plaats als het gaat om de bescherming van de kwetsbaren in de samenleving. Ik dank Jos van harte voor zijn waardevolle bijdrage aan het gezondheidsrechtelijke discours en ik hoop dat wij nog vele jaren mogen profiteren van zijn kennis en inzichten. 